\title{
STUDY OF MICROSTRUCTURE AND THERMAL PROPERTIES OF AS-CAST HIGH CARBON AND HIGH CHROMIUM TOOL STEEL
}

\author{
Dragan Manasijevic ${ }^{1 *}$, Žarko Radović ${ }^{2}$, Nada Štrbac ${ }^{1}$, Ljubiša Balanović $^{1}$, \\ Uroš Stamenkovićl, Milan Gorgievski ${ }^{1}$, Duško Minić, ${ }^{3}$, Milena Premović ${ }^{3}$, \\ Tamara Holjevac Grgurić, and Nebojša Tadic ${ }^{2}$ \\ ${ }^{1}$ University of Belgrade, Technical faculty in Bor, VJ12, 19210 Bor, Serbia \\ ${ }^{2}$ University of Montenegro, Faculty of Metallurgy and Technology, \\ Cetinjski put, bb, 81000, Podgorica, Montenegro \\ ${ }^{3}$ University of Priština, Faculty of Technical Science, \\ Kneza Miloša 7, 4000 Kosovska Mitrovica, Serbia \\ ${ }^{4}$ University of Zagreb, Faculty of Metallurgy, \\ Aleja narodnih heroja 3, Sisak, Croatia
}

Received 03.10.2018

Accepted 10.12.2018

\begin{abstract}
This work aims to investigate the microstructural and thermal properties of as-cast high carbon and high chromium cold work tool steel. The microstructure was investigated by using scanning electron microscopy with energy dispersive spectroscopy (SEM-EDS) and X-ray diffraction (XRD) method. It was determined that at room temperature the microstructure of the investigated tool steel includes a lamellar network of $\mathrm{M}_{7} \mathrm{C}_{3}$ carbide precipitates along grain boundaries of ferrite grains in the base. Thermal diffusivity, specific heat capacity and thermal conductivity of the investigated steel alloy were determined in the temperature interval from 25 to $400{ }^{\circ} \mathrm{C}$ by using the laser-flash method. Thermal conductivity increases from 24.9 at $25{ }^{\circ} \mathrm{C}$ to $26.9 \mathrm{~W} / \mathrm{m} \cdot \mathrm{K}$ at $400{ }^{\circ} \mathrm{C}$. Phase transition temperatures in the temperature region from room temperature to $1250^{\circ} \mathrm{C}$ were experimentally determined using differential scanning calorimetry (DSC). One endothermic effect in the temperature interval from 803 to $820{ }^{\circ} \mathrm{C}$, corresponding to the ferrite/austenite phase transformation, was detected during sample heating. Experimental results were compared with the results of phase equilibria calculations obtained from the ThermoCalc software and TCFE6 database.
\end{abstract}

Keywords: high alloy tool steel; as-cast; scanning electron microscopy; thermal conductivity; differential scanning calorimetry.

\footnotetext{
* Corresponding author: Dragan Manasijević,dmanasijevic@tfbor.bg.ac.rs
} 


\section{Introduction}

High carbon and high chromium cold work tool steels are extensively used in industry because of their excellent hardenability and high wear resistance [1, 2]. Typical applications of these tool steels include shear blades, trimming and cutting tools, blanking dies, punches, forming and bending rolls [1-3].

High-carbon and high-chromium steels possess excellent abrasion resistance and a high degree of dimensional stability in heat treatment. They are highly resistant to softening at elevated temperatures and moderately resistant to decarburizing and can be nitrided [4].

Although cold work tool steels have been extensively studied in the heat-treated conditions [5-7], investigations of their microstructural and thermal characteristics in ascast conditions are rare.

The knowledge of microstructure, solidification properties and thermal conductivity of the selected steel should help to improve the design of its structures and components. Thermal conductivity represents an important thermophysical property of material because it controls the size of the temperature gradients which occur in components during their production and use.

In this work microstructure, phase transitions and thermal properties including thermal diffusivity, specific heat and thermal conductivity of the high carbon, high chromium tool steel ingot (165XCrMoW12 (DIN)) were experimentally investigated using: scanning electron microscopy with energy dispersive spectroscopy (SEM-EDS), $\mathrm{X}$-ray powder diffraction (XRD) thermal diffusivity measurements, differential scanning calorimetry (DSC) and thermodynamic calculation of phase equilibria. Obtained results represent a contribution to a better knowledge of microstructural and thermal properties of the investigated high alloy tool steel in its as-cast state.

\section{Experimental procedure}

\section{Materials}

High carbon and high chromium tool steel was produced in an induction furnace and cast into a standard ingot $\left(60 \mathrm{~kg}, \mathrm{t}_{\text {cast }}-1460{ }^{\circ} \mathrm{C}\right)$. All investigated samples were obtained from the cast ingot. The chemical composition of the investigated samples is given in Table 1.

Table 1. Chemical composition of the investigated tool steel determined by X-ray fluorescence (XRF) technique (in wt.\%).

\begin{tabular}{lllllllllll}
\hline $\mathrm{C}$ & $\mathrm{Si}$ & $\mathrm{Mn}$ & $\mathrm{Cr}$ & $\mathrm{Ni}$ & $\mathrm{Mo}$ & $\mathrm{W}$ & $\mathrm{V}$ & $\mathrm{P}$ & $\mathrm{S}$ & $\mathrm{Fe}$ \\
\hline 1.65 & 0.35 & 0.32 & 12.5 & 0.29 & 0.64 & 0.45 & 0.21 & 0.032 & 0.029 & Balance \\
\hline
\end{tabular}

\section{Microstructure investigation}

Metallographic samples were prepared using conventional grinding and polishing steps and etched at room temperature in 2\% Nital reagent for 2-3 s before conducting SEM-EDS. TESCAN VEGA3 scanning electron microscope with energy dispersive spectroscopy (EDS) (Oxford Instruments X-act) was used to observe the microstructure of the investigated steel sample and the measurements were carried out at $20 \mathrm{kV}$. 
Compositions of coexisting phases were determined using EDS area and point analysis. SEM images of the microstructures were taken on the polished and etched surfaces of the studied steel sample in the secondary electron (SE) and back-scatter electrons (BSE) modes.

Identification of co-existing phases was also made using the XRD technique. Powder XRD data were recorded on a D2 PHASER (Bruker, Karlsruhe, Germany) powder diffractometer equipped with a dynamic scintillation detector and ceramic X-ray $\mathrm{Cu}$ tube (KFL-Cu-2K) in a $2 \theta$ range from $10^{\circ}$ to $75^{\circ}$ with a step size of $0.02^{\circ}$. The detected XRD pattern was analyzed using ICDD databases PDF2 (2013).

\section{Thermal diffusivity and specific heat measurements}

Thermal diffusivity and specific heat were measured using a Discovery Xenon Flash (DXF-500) device. The DXF-500 is equipped with nickel-chrome heaters and an air-cooled aluminum shell. The heating rate was $10{ }^{\circ} \mathrm{C} / \mathrm{min}$ and the thermal diffusivity measurements were performed within the temperature range from 25 to $400{ }^{\circ} \mathrm{C}$ in the vacuumed furnace filled with inert gas. Measurement began when the temperature reached a particular value and stayed stable. A liquid nitrogen-cooled IR detector made sample temperature measurements. The steel sample was shaped into a round disk (12.6 $\mathrm{mm}$ in diameter and $2 \mathrm{~mm}$ thick with plane-parallel ground end faces).

\section{Thermal analysis}

Thermal analysis of the investigated steel was carried out using an SDT Q600 (TA Instruments). A sample weighing $50 \mathrm{mg}$ was investigated at a heating rate of $10{ }^{\circ} \mathrm{C} / \mathrm{min}$ from room temperature up to $1250^{\circ} \mathrm{C}$ in a nitrogen atmosphere to prevent oxidation. The reference material was an empty alumina crucible.

\section{Results and discussion}

Phase equilibria calculation

Thermodynamic calculations of phase equilibria can provide useful information about expected phases, their amounts, and phase transition temperatures [6]. In this work thermodynamic calculation was performed using ThermoCalc software and TCFE6 database [8]. Calculated phase diagram with the labeled composition of the investigated tool steel is shown in Fig. 1. According to the calculated results for the composition of $1.65 \mathrm{wt}$ \% C, upon cooling, solidification starts with the formation of austenite (FCC_A1 phase) at $1392{ }^{\circ} \mathrm{C}$. At $1273{ }^{\circ} \mathrm{C} \mathrm{M}_{7} \mathrm{C}_{3}$ carbide starts simultaneous crystallization with austenite $\left(\mathrm{L} \rightarrow \gamma+\mathrm{M}_{7} \mathrm{C}_{3}\right)$. Complete solidification of steel is finished at $1256{ }^{\circ} \mathrm{C}$. Precipitation of $\mathrm{M}_{23} \mathrm{C}_{6}$ carbide starts at $851^{\circ} \mathrm{C}$. Austenite (FCC_A1) to ferrite (BCC_A2) phase transition starts at 809 and ends at $793{ }^{\circ} \mathrm{C}$. At room temperature, the steel microstructure primary consists of ferrite, $\mathrm{M}_{7} \mathrm{C}_{3}$, and $\mathrm{M}_{23} \mathrm{C}_{6}$ carbide. However, during rapid solidification of steel metastable supersaturated austenite can be retained in the microstructure [2, 9-11]. 


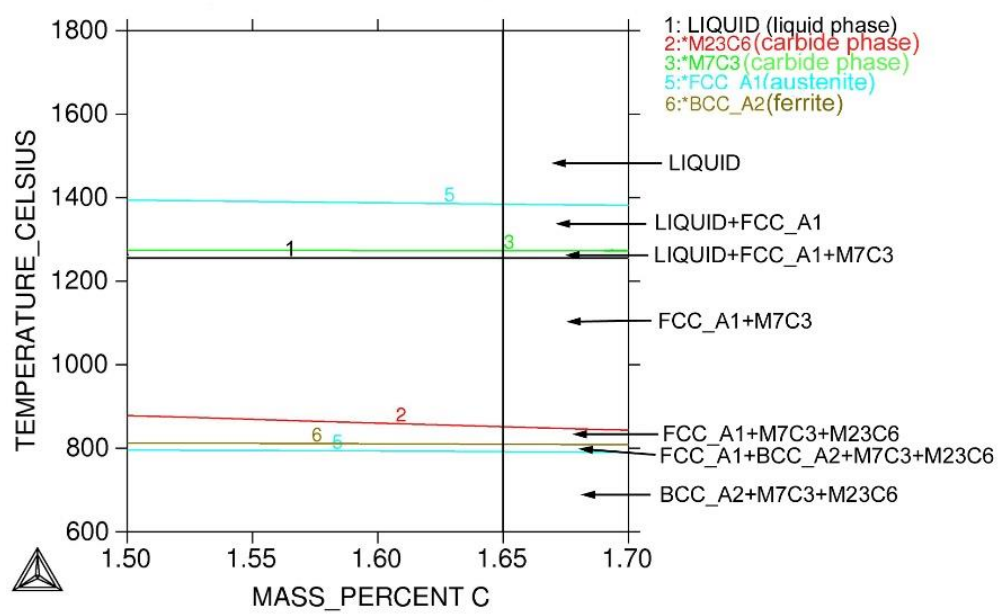

Fig. 1. Calculated pseudo-binary phase diagram of high chromium, high carbon tool steel with the composition of the tool steel (1.65 wt.\% C) labeled by a vertical line.

\section{Microstructure investigation}

The microstructure of the as-cast high alloy tool steel was investigated using SEMEDS analysis. Characteristic SEM micrographs of the etched, and polished without etching steel microstructure are shown under different magnifications in Figs. 2a-b and 3a-b.

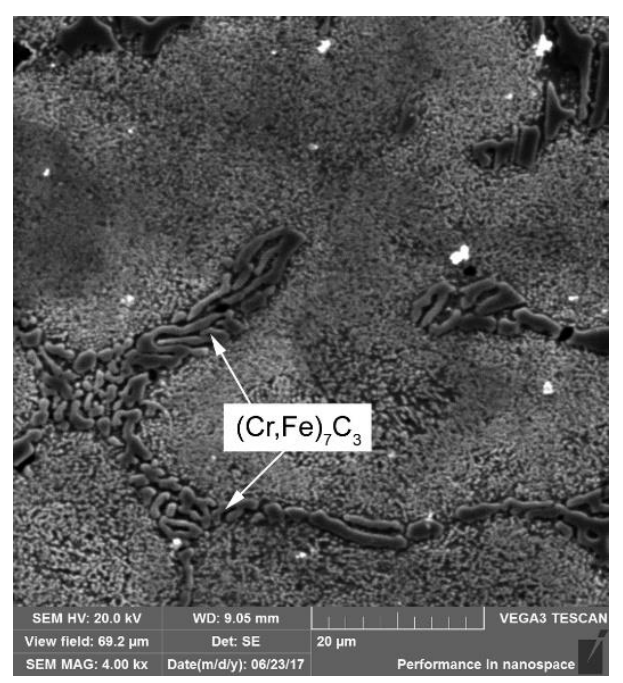

(a)

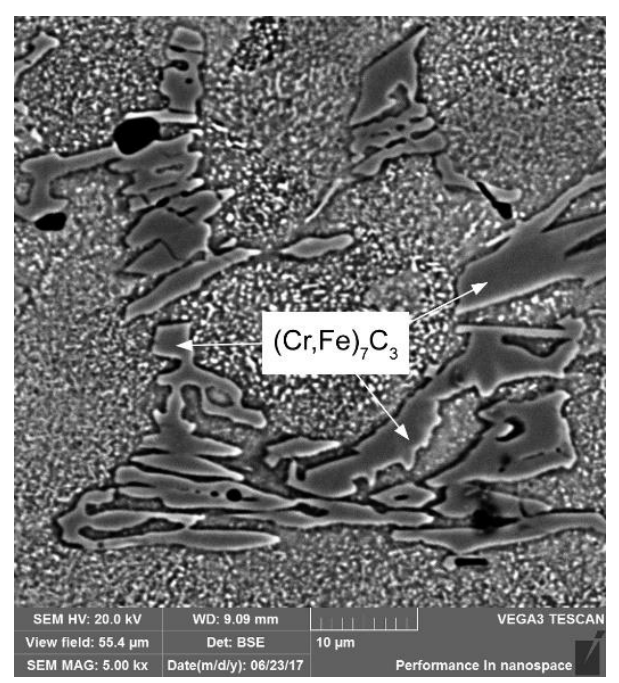

(b)

Fig. 2. SEM images of the etched steel microstructure with eutectic carbides network under different magnifications: (a) 4000x; (b) 5000x. 


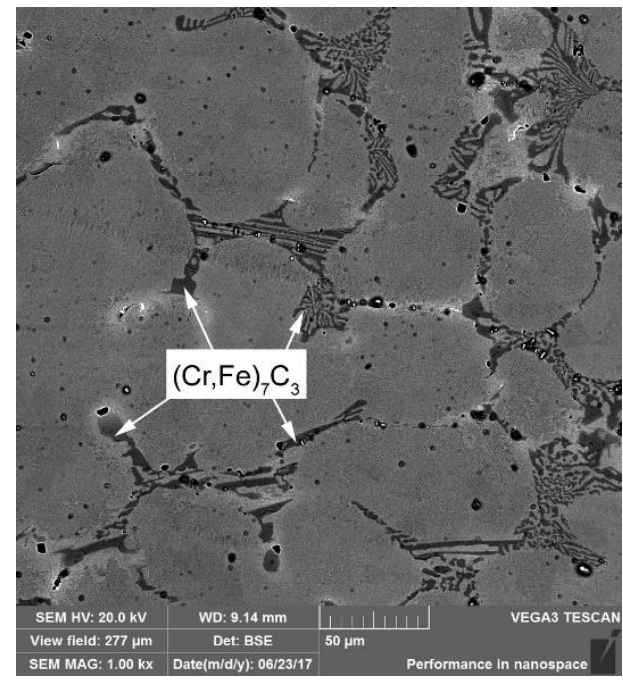

(a)

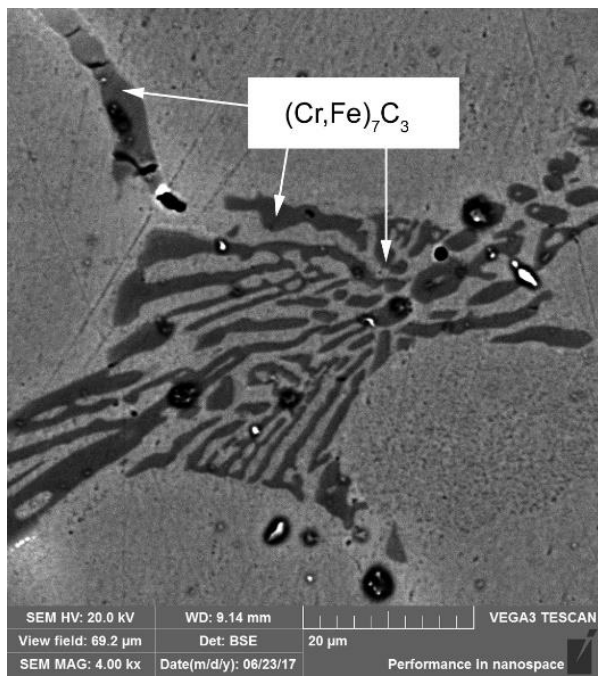

(b)

Fig. 3. SEM images of the polished without etching steel microstructure showing the eutectic carbides network under different magnifications: (a) 1000x; (b) 4000x.

Based on the results of SEM-EDS analysis $(\mathrm{Cr}, \mathrm{Fe})_{7} \mathrm{C}_{3}$ eutectic carbides were identified. In the as-cast sample $(\mathrm{Cr}, \mathrm{Fe})_{7} \mathrm{C}_{3}$ carbides have precipitated along grain boundaries, forming a continuous carbide network. Secondary $\mathrm{M}_{23} \mathrm{C}_{6}$ carbide precipitates, which were predicted by thermodynamic calculation (Fig. 1), were not observed. The average chemical composition of the identified carbide phase determined by EDS analysis is presented in Table 2.

Table 2. The average chemical composition of the $(\mathrm{Cr}, \mathrm{Fe})_{7} \mathrm{C}_{3}$ carbide phase determined by EDS analysis with calculated standard uncertainties.

\begin{tabular}{lccccccccccc}
\hline \multirow{2}{*}{ Phase } & \multicolumn{10}{c}{ Average phase composition (at. \%) } \\
& $\mathrm{Fe}$ & $\mathrm{C}$ & $\mathrm{Si}$ & $\mathrm{Mn}$ & $\mathrm{Cr}$ & $\mathrm{Ni}$ & $\mathrm{Mo}$ & $\mathrm{W}$ & $\mathrm{V}$ & $\mathrm{P}$ & $\mathrm{S}$ \\
\hline$(\mathrm{Cr}, \mathrm{Fe})_{7} \mathrm{C}_{3}$ & $37.0 \pm 4.3$ & $28.4 \pm 1.0$ & 0.0 & 0.0 & $33.3 \pm 3.4$ & 0.0 & 0.0 & $0.3 \pm 0.03$ & $1.0 \pm 0.2$ & 0.0 & 0.0 \\
\hline
\end{tabular}

From Table 2 it could be concluded that the $\mathrm{M}_{7} \mathrm{C}_{3}$ carbides are mainly composed of $\mathrm{Fe}, \mathrm{Cr}$, and $\mathrm{C}$, while small amounts of $\mathrm{V}$ and $\mathrm{W}$ are also detected.

$\mathrm{X}$-ray diffraction (XRD) was applied to investigate the microstructure of the high alloy tool steel further. The detected XRD pattern for the investigated high alloy tool steel is shown in Fig. 4. 


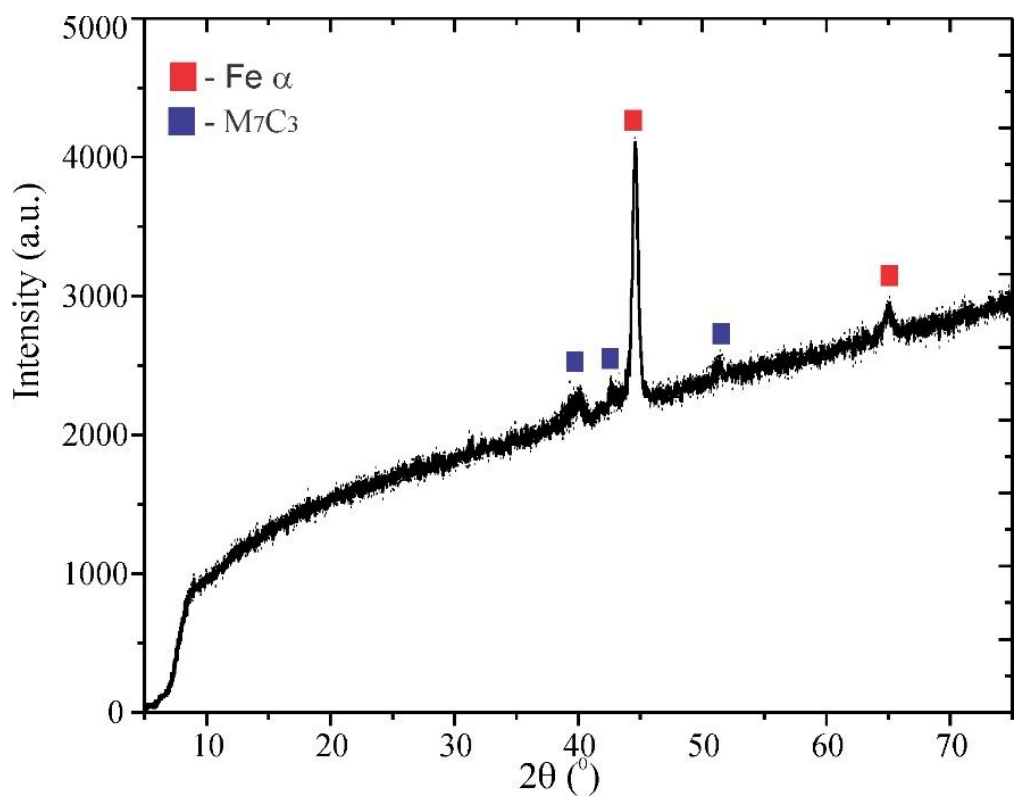

Fig. 4. XRD pattern for the investigated high alloy tool steel. carbides.

$\mathrm{XRD}$ analysis revealed the presence of ferrite and confirmed the existence of $\mathrm{M}_{7} \mathrm{C}_{3}$

Based on the results of SEM-EDS and XRD analysis it can be concluded that the microstructure of the investigated tool steel primary consists of ferrite and $(\mathrm{Cr}, \mathrm{Fe})_{7} \mathrm{C}_{3}$ carbides which are in general agreement with the result of phase equilibria calculation presented in Fig. 1. Due to the high chromium content, which causes the shifting of the equilibrium $\mathrm{Fe}-\mathrm{Fe}_{3} \mathrm{C}$ phase diagram to the left, this steel is often called ledeburitic steel. Ledeburitic type of microstructure, represented by the presence of austenitic-carbide eutectic, is frequently found in steels alloyed with strong carbide-forming elements such as $\mathrm{Cr}, \mathrm{W}, \mathrm{V}, \mathrm{Nb}$, and $\mathrm{Ti}$, in which the appropriate alloy carbides replace cementite, often at relatively low alloying element concentrations [12]. It has been reported in the literature that in high carbon, high chromium steels microstructure based on the primary formed an irregular network of eutectic carbides can be modified by applying annealing heat treatment [13] and by addition of modifying elements [14], which leads to the improvement of ductility and impact toughness.

\section{Thermal conductivity measurements}

Laser-flash technique [15] is based on uniform irradiation of a disc-shaped sample over its front face with a very short pulse of energy. The sample's thermal diffusivity $\alpha$ is calculated using the following equation $[15,16]$ :

$$
\alpha=\frac{1.37 L^{2}}{\pi^{2} t_{1 / 2}}=0.1388 \frac{L^{2}}{t_{1 / 2}}
$$


where $L$ represents the thickness of the sample and $t_{1 / 2}$ is the half-rise time, defined as time interval required for the rear surface temperature to reach half of the maximal temperature increase.

The specific heat capacity $C_{p}$ of a material represents the amount of energy required to raise a unit mass of the material by one unit of temperature at constant pressure:

$$
C p=\frac{Q}{m \Delta T}
$$

where $C_{p}$ is specific heat capacity $(\mathrm{J} / \mathrm{kgK}), \mathrm{m}$ is mass $(\mathrm{kg}), \Delta T$ is changed in temperature $(\mathrm{K})$, and $Q$ is the amount of energy $(\mathrm{J})$.

Specific heat capacity can be measured with the laser-flash method by comparing the temperature rise of the sample to the temperature rise of a reference sample of known specific heat capacity, tested under the same conditions [16].

Based on the measured values of the thermal diffusivity and specific heat capacity, the thermal conductivity of the investigated sample can be calculated using a relationship [15]:

$$
\lambda=\alpha \cdot \rho \cdot C p
$$

where $\lambda$ is thermal conductivity (W/mK), $\alpha$ is thermal diffusivity $\left(\mathrm{m}^{2 /} \mathrm{s}\right), \rho$ is density $\left(\mathrm{kg} / \mathrm{m}^{3}\right)$, and $C \mathrm{p}$ is specific heat capacity $(\mathrm{J} / \mathrm{kgK})$.

The calculated values of thermal diffusivity, specific heat capacity and thermal conductivity of the investigated high alloy tool steel in the temperature range from 25 to $400{ }^{\circ} \mathrm{C}$ are presented in Table 3 .

Table 3. Thermal diffusivity, specific heat capacity and thermal conductivity of the investigated high alloy steel in the temperature interval from 25 to $400{ }^{\circ} \mathrm{C}$.

\begin{tabular}{cccc}
\hline $\begin{array}{c}\text { Temperature } \\
\left({ }^{\circ} \mathrm{C}\right)\end{array}$ & $\begin{array}{c}\text { Thermal diffusivity } \\
\left(\mathrm{cm}^{2} / \mathrm{s}\right)\end{array}$ & $\begin{array}{c}\text { Specific heat capacity } \\
(\mathrm{J} / \mathrm{kg} \cdot \mathrm{K})\end{array}$ & $\begin{array}{c}\text { Thermal conductivity } \\
(\mathrm{W} / \mathrm{m} \cdot \mathrm{K})\end{array}$ \\
\hline 25 & 0.0623 & 518.1329 & 24.9258 \\
100 & 0.0620 & 526.8658 & 25.2216 \\
200 & 0.0609 & 556.4617 & 26.1615 \\
300 & 0.0590 & 581.0959 & 26.4783 \\
400 & 0.0561 & 621.7637 & 26.9317 \\
\hline
\end{tabular}

Temperature dependence of thermal conductivity for the investigated high alloy tool steel is graphically presented in Fig. 5. 


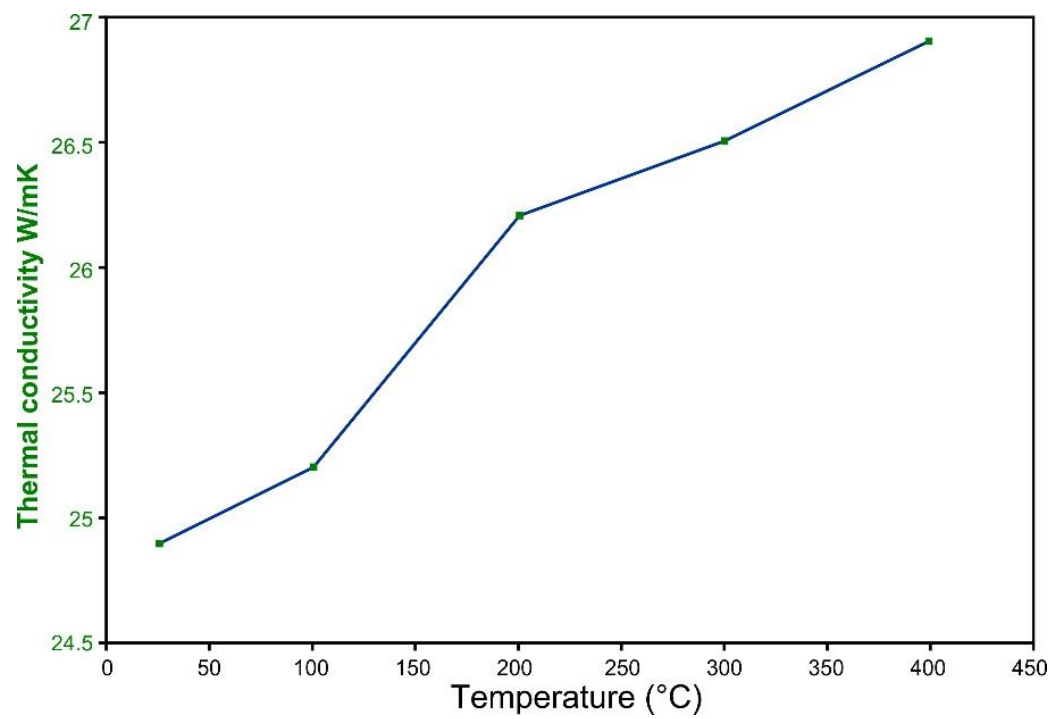

Fig. 5. Temperature dependence of thermal conductivity for the investigated high alloy tool steel in the temperature range from 25 to $400{ }^{\circ} \mathrm{C}$.

From Table 3 it can be seen that, in the investigated temperature interval, thermal diffusivity decreases and specific heat capacity increases with increasing temperature. The thermal conductivity of the investigated tool steel consistently increases from 24.9 $\mathrm{W} / \mathrm{m} \cdot \mathrm{K}$ at $25{ }^{\circ} \mathrm{C}$ to $26.9 \mathrm{~W} / \mathrm{m} \cdot \mathrm{K}$ at $400{ }^{\circ} \mathrm{C}$. These low values of thermal conductivity are to be expected for high alloy steels [17]. It is a well-established fact that at ambient temperature, high alloy steels have much lower thermal conductivity compared to the cast irons and carbon steels due to the large number of alloying elements [17, 18]. Pure iron has the highest value of thermal conductivity followed by carbon steels, alloy steels and then by high alloy steels [16-18]. However, with an increase in temperature the thermal conductivities of irons and low alloyed steels decrease, while the conductivities of high alloy steels increase as is shown in Fig. 5 [17, 18].

\section{Thermal analysis}

Phase transition temperatures of the investigated steel were investigated using DSC heating curves in the temperature interval from 25 to $1250{ }^{\circ} \mathrm{C}$ with the heating rate of $10{ }^{\circ} \mathrm{C} / \mathrm{min}$. Only one endothermic effect was identified during heating of the investigated steel sample (Fig. 6). The extrapolated onset temperature of the identified peak was $803.5^{\circ} \mathrm{C}$, the peak maximum temperature was $814.3^{\circ} \mathrm{C}$, and the end of the peak was at $820.5^{\circ} \mathrm{C}$. According to the results of phase equilibria calculation shown in Fig. 1 the thermal interval of ferrite/austenite phase transformation is from 809 to $793{ }^{\circ} \mathrm{C}$; therefore the identified thermal endothermic effect can be considered as phase transformation of ferrite to austenite. The measured temperature of the solid-state phase transformation is in good agreement with the experimental result of Bombac et al. [6] and somewhat lower than experimentally determined temperature by Moravčik et al. [19]. 


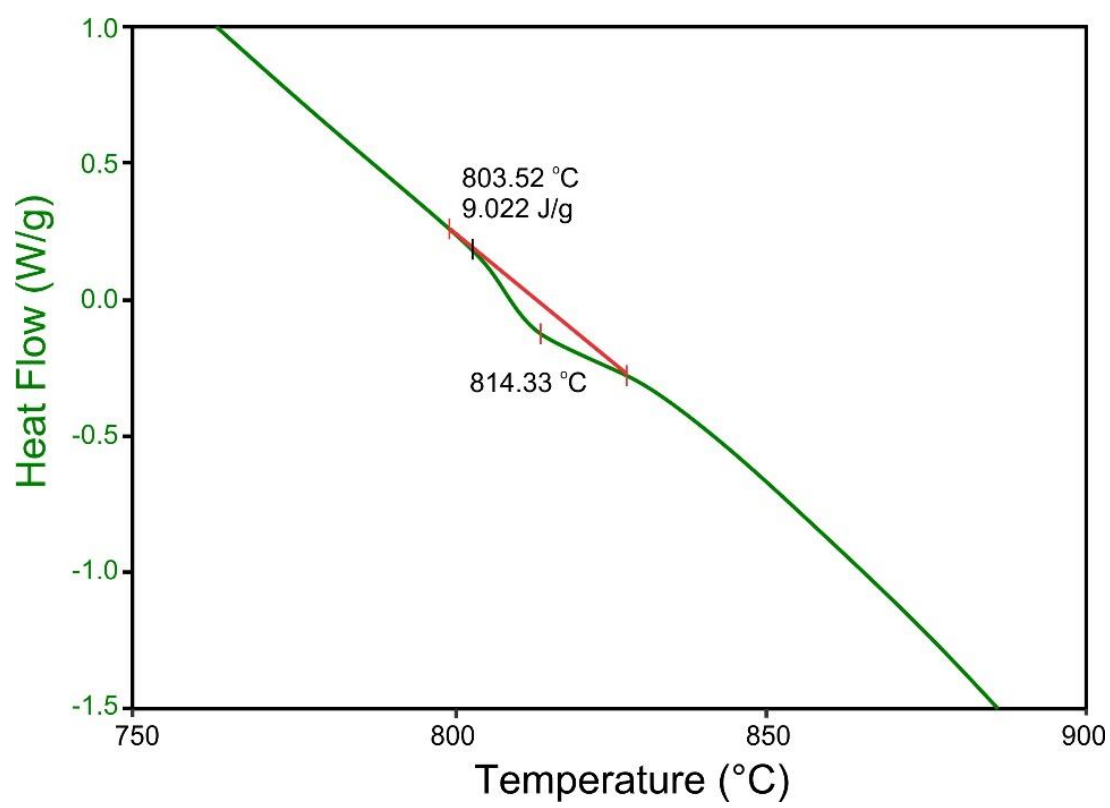

Fig. 6. Part of the DSC heating curve for the investigated sample of the high alloy tool steel with the endothermic effect in the temperature range from 803 to $820^{\circ} \mathrm{C}$.

\section{Conclusions}

Microstructure and thermal properties of high carbon, high chromium tool steel in the as-cast state were investigated in this work. Based on the results presented in this paper it can be concluded that the investigated tool steel shows a ledeburitic type of microstructure with $\mathrm{M}_{7} \mathrm{C}_{3}$ austenitic-carbide eutectics network along the grain boundaries of the matrix phase. The precipitated $\mathrm{M}_{7} \mathrm{C}_{3}$ carbides have a lamellar shape and are composed mainly of $\mathrm{Fe}, \mathrm{Cr}$ and $\mathrm{C}$. Experimentally determined temperature dependence of thermal conductivity in the temperature interval from 25 to $400{ }^{\circ} \mathrm{C}$ show a consistent increase from 24.9 to $26.9 \mathrm{~W} / \mathrm{m} \cdot \mathrm{K}$. One endothermic effect in the temperature interval from 803 to $820{ }^{\circ} \mathrm{C}$, is contributed to the ferrite/austenite phase transition and at temperatures below $800{ }^{\circ} \mathrm{C}$ austenite is wholly converted into ferrite and carbides.

\section{Acknowledgments}

This study was done in the frame of the bilateral project between the University of Belgrade, Technical Faculty in Bor (Serbia) and University of Podgorica, Faculty of Metallurgy and Technology (Montenegro) entitled "Investigation of thermal, structural and mechanical properties of high alloy tool steels". 


\section{References}

[1] G. Roberts, G. Krauss, R. Kennedy: Tool Steels, Materials Park: ASM International, 1998.

[2] J. Valloton, D. M. Herlach, H. Henein, D. Sediako: Metall Mat Trans A, 48 (10) (2017) 4735-4743.

[3] T. Večko Pirtovšek, G. Kugler, M. Terčelj: Mater Charact, 83 (2013) 97-108

[4] T. Packiaraj Rajendran, N. Rajesh Jesudoss Hynes, T. Christopher: J Braz Soc Mech Sci Eng, 40 (2018) Article: 316.

[5] T. Amine, J W. Newkirk, H. El-Din, F. El-Sheikh, F. Liou: Int J Adv Manuf Technol, 73 (9-12) (2014) 1427-1435.

[6] D. Bombac, M. Fazarinc, A. Saha Podder, G. Kugler: J Mater Eng Perform, 22 (3) (2013) 742-747.

[7] H. Torkamani, Sh. Raygan, J. Rassizadehghani: Mater Design, 54 (2014) 1049-1055.

[8] J. O. Andersson, T. Helander, L. Höglund, P. Shi, B. Sundman: Calphad, 26 (2) (2002) 273-312.

[9] D. Aišman, H. Jirkova, B. Mašek: J Alloy Compd, 536 (2012) S204-S207.

[10] M. N. Mohammed, M. Z. Omar, J. Syarif, Z. Sajuri, M. S. Salleh, K. S. Alhawari, The Scientific World Journal, Article ID 828926, (2013), 7 pages.

[11] S. Kahrobaee, M. Kashefi: J Mater Eng Perform, 24 (3) (2015) 1192-1198.

[12] E. C. Bain: Alloying Elements in Steels, ASM, Cleveland, Ohio, USA, 1939.

[13] G. Ramesh, R. Rahul, M. Pradeep, P. Sreehari, S. Ramesh Kumar: Materials Today: Proceedings, 5 (2018) 2733-2737.

[14] M.A. Hamidzadeh, M.Meratian, M. Mohammadi Zahrani: Mat Sci Eng A-Struct, 556 (2012) 758-766.

[15] W. J. Parker, R. J. Jenkins, C. P. Butler, G. L. Abbott: J Appl Phys, 32 (9) (1961) 1679.

[16] D. Manasijević, Ž. Radović, N. Štrbac, Lj. Balanović, U. Stamenković, M. Gorgievski, M. Premović, T. Holjevac Grgurić, N. Tadić: Mater Test, 60 (12) (2018) $1175-1178$.

[17] S. M. Shelton: Bureau of Standards Journal of Research, 12 (1934) 441.

[18] M. J. Peet, H. S. Hasan, H. K. D. H. Bhadeshia: Int J Heat Mass Tran, 54 (11-12) (2011) 2602-2608.

[19] R. Moravčík, M. Štefániková, R. Čička, L. Čaplovič, K. Kocúrová, R. Šturm: Strojniški vestnik - Journal of Mechanical Engineering, 58 (12) (2012) 709-715.

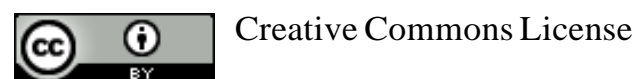

This work is licensed under a Creative Commons Attribution 4.0 International License. 